\title{
New Technologies and Innovative Solutions in the Development Strategies of Energy Enterprises
}

\author{
Piotr F. Borowski ${ }^{a^{*}}$ \\ ${ }^{a}$ Institute of Mechanical Engineering, Warsaw University of Life Sciences, 166 Nowoursynowska str., 02-787 Warsaw, Poland.
}

Received 12 April 2020; Revised 19 May 2020; Accepted 25 May 2020; Published 01 June 2020

\begin{abstract}
Energy companies face challenges arising from the ecological, social, and legal environments. The reduction of negative impacts on the environment and society while maintaining sustainable development affects the formation of new development strategies and the push to introduce state-of-the-art innovative technologies. The main aim of the research is to analyze the importance and role of the adaptation strategy in external requirements and to determine the mechanisms of the occurrence of passive and active adaptation. As a new approach to carrying out strategic analysis, two models were used simultaneously (inductive and hypothetical-deductive), which allowed for the realization of qualitative (interviews, observations) and quantitative (statistical analysis) research methods generally called mixed methods. The study was conducted on the basis of a mixed-method analysis of the adaptation strategies of enterprises from the energy sector. The results of the conducted research show the influence of particular macroeconomic elements (e.g., technologies, ecologies) on making strategic decisions. The issue of adapting an enterprise to its environment is also related to its involvement in the Research and Development (R\&D) sphere. Depending on the size of the company, there are different amounts dedicated to R\&D. Regulations and the technological environment force innovations by energy companies in the direction of reducing their harmful impact on the environment and society. Legal and political factors (both national and EU) determine the activities of power companies (in each group: small, medium, and large) and the choice of adaptation strategies. The intensity of adaptation to the requirements of environmental changes depends on the size of the company. As power companies apply passive adaptation strategies, and as they increase their position in the market, they begin to implement an active adaptation strategy.
\end{abstract}

Keywords: Strategic Management; Adaptation Strategy; Energy Sector; Quantity Methods; Quality Methods; Induction Methods; Hypothetic-deduction Methods; Society; Sustainability.

\section{Introduction}

Basically, all people are dealing with the energy sector as the end consumers of energy. The whole sector can be considered as a system consisting of individual services as follows: transmission service, distribution service, sales service. In the energy sector, all the mentioned services are outsourced from the main core of the energy business according to the unbundling of the power market [1]. The key issues for the final customer are the continuity of supplies and acceptable energy costs. Energy and social aspects meet at the point of building responsible strategies in energy companies. However, this is influenced by the strategies of individual energy companies, and this aspect is the main focus of this realized research. Due to the growing dynamics in task-oriented environments of enterprises, the strategy of adaptation has become, over the past decade, a central topic for management and strategy building. The situations of enterprises operating in a turbulent and uncertain environment are constantly changing [2], for example,

* Corresponding author: piotr_borowski@sggw.edu.pl

\section{doi http://dx.doi.org/10.28991/HIJ-2020-01-02-01}

$>$ This is an open access article under the CC-BY license (https://creativecommons.org/licenses/by/4.0/).

(C) Authors retain all copyrights. 
the very changeable oil market with its crises and unpredictable prices [3]. According to the latest forecasts, the level of uncertainty in the business environment will increase in the coming years $[4,5]$. Uncertainty in organizations is to face it in the choice of appropriate strategies [6]. Due to those changes, managers or chief executives must anticipate, articulate and manage change. Technical innovations were important for the development of societies in the past and will become even more important in the coming years. Technologies will play a key role and their importance will increase, including in the energy sector, clean technologies, and reducing negative impacts on society [7, 8]. The establishment of Startups with high tech innovations is becoming more and more popular among energy companies. The creation of countries well-being and their dynamic sustainable development depends on the competitiveness of their firms, which, in turn, relies fundamentally on the capabilities of their entrepreneurs and managers [9]. Managers of all kinds of enterprises, and in our case, managers of power plant utilities, also pay particular attention to the organization's innovations such as product/service innovation, process and governance innovation [10-12].

The second decade of the $21^{\text {st }}$ century is the growing importance of the ecological environment and moving towards sustainable development. Ecological and social thinking plays an important role in sustainable development and environmental protection [13]. Legislation, directives and regulations affecting the ecological environment are quite complex and are characterized by a high degree of variability and often can cause new conflicts and inconsistencies in the field of sustainable development [14, 15], which translates into increased the level of business risk in the energy market [16]. Enterprises from every industry and especially from the energy sector strongly feel the impact of new directives and regulations related to ecology, among others reduction of $\mathrm{CO}_{2}$ emissions, and thus reducing the negative impact on the environment [17]. In enterprises in the energy sector, the reduction of harmful emissions in the conditions of power installations is an important element of the actions taken. In the enterprises of energy sector we can observe the significant role of managers, but also adaptability and flexibility are the important issue, because the choice of the right strategy guarantees energy security and, as a consequence, the security of the economic development of the entire country [18].

In the literature there is a lack of research concerning energy sector combined with adaptation strategy, therefore this paper joins empirical findings with theoretical interpretation in order to fulfil this theoretical gap. Mainly research and scientific articles concerns adaptation to climate change [19,20] or changes implementation due to the digital technologies, renewable energy, and prosumers requires [21, 22].

The novelty of the topic discussed in this manuscript is to combine adaptation strategies with macro-environment factors affecting the undertaking of energy managers. In the sector of energy enterprises this is an important, pivotal issue, because the choice of the right strategy guarantees energy security and, as a consequence, the security of the economic development of the entire country. Not only on the production side but above all on the consumer side, energy is a key factor for the safe functioning of the economy, e.g. of the food industry enterprises [23]. In industrialized countries, the key to economic growth and expansion is their power sectors' proper performance. Countries with higher GDP invest more in renewable energy, and this type of energy production and consumption is more widely used and more popular [24] and policymakers should support and encourage in order to invest and use of renewable energy in the future [25, 26]. Green energy it also involves adjusting the variable (unpredictable and uneven production) supply of energy from renewable sources (solar, wind) to the reported demand [27]. The indispensability of electricity in all economic processes and consumption makes it a public good and the rationalization of the costs of its production, proper supply level and meeting demand as well as physical delivery conditions is a strategic challenge for the economy of each country that translates into appropriate management of electric utilities [28, 29].

In order to learn the directions of development of energy enterprises (1) research questions were formulated and empirical research (observations and deep interview) was carried out, which allowed verification of research questions and generalization (induction method) and (2) critical theoretical analysis was carried out to confirm or eliminate the hypotheses (method hypothetical deductive).

\section{Material and Methods}

In management sciences, research can be conducted using methods and techniques that are presented in Figure 1.

However, for several years in management sciences and broadly understood social sciences, mixed methods were adopted, accepted and used. It is assumed that the use of a combination of quantitative and qualitative methods provides the possibility of greater flexibility in undertaking research, generating better supported arguments based on research data and greater importance for a wider range of stakeholders. Using a mixed methods approach (MMA) it is expected that the combination of quantitative and qualitative methods will eliminate the errors of individual methods and complement the results obtained at individual stages of the research process [30-32]. Therefore, this study uses MMA to investigation the relationship between the macro-environment and the enterprise in the process of implementing the strategy of adaptation. 


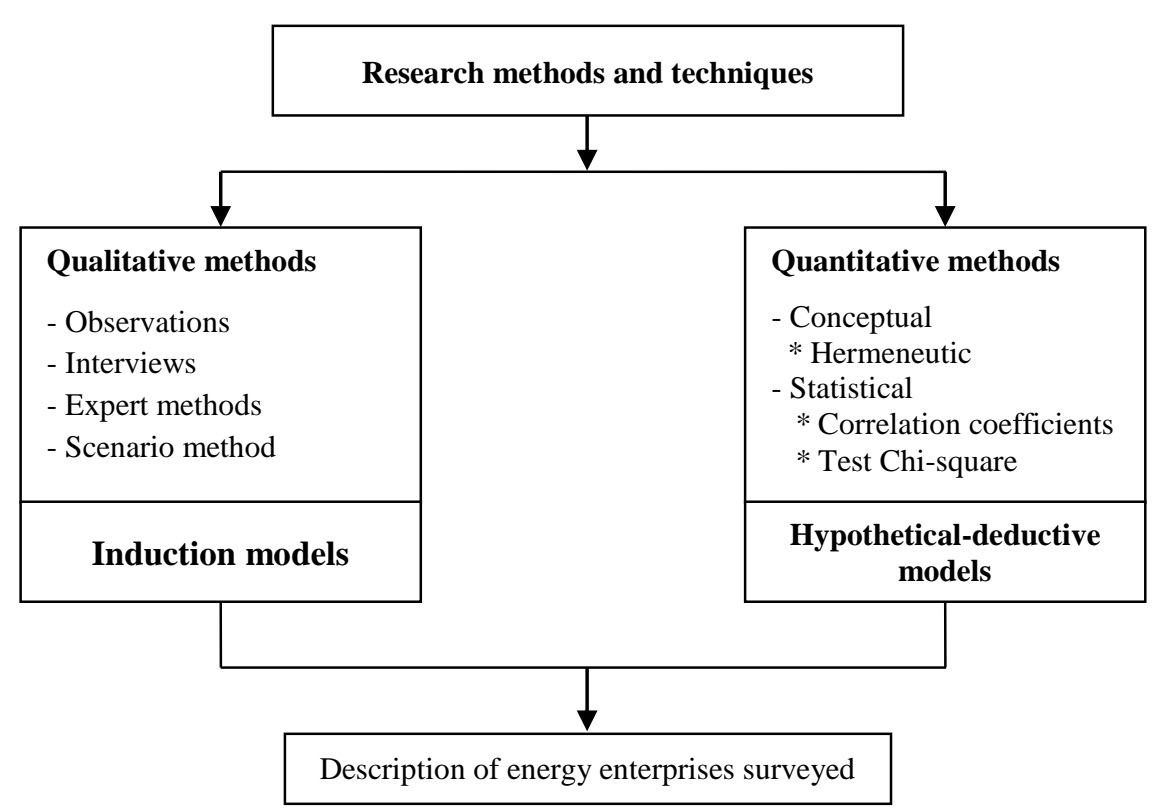

Figure 1. Research methods and techniques used in the research

\subsection{Qualitative Research Method}

The continuous increase of interest in the world of science in qualitative research in the field of management sciences, which is clearly observed in recent decades, confirms the growing importance of qualitative research in relation to issues related to organizational and management matters and also in energy sector [33].

Qualitative research is characterized by induction models [34], in which a priori image of reality is not assumed, but research questions are formulated and then generalizations are formulated on the basis of empirical research [35]. Qualitative research uses empiricism and induction. In empirical science it is a method based on deriving generalizations based on experiments and observation of facts. Qualitative methods include four main methods (techniques): observation, analysis of texts and documents, interview (surveys), recording and transcription. These methods do not occur in isolation from each other, on the contrary they are often combined as e.g. observation with an interview triangulation $[36,37]$. Nowadays, very often survey interviews take place via the Internet [38]. The induction model is based on the assumption that the more diverse cases confirm a given hypothesis, the more likely it is and we can trust it to some extent, sometimes even to the extent that it becomes the law of science, although there is often a discussion about the role of induction in qualitative research $[39,40]$. The probability of correct inference obtained by the induction method will be the greater, the more objects are examined and it turns out that they all have the same characteristics, and the more varied they will be and the more diverse the conditions under which the observations were made. In other words, it can be said that the more confirmed individual sentences about facts, observational sentences, the more their generalization, theoretical sentence, i.e. the hypothesis is credible. Any inductive reasoning begins with judgments about empirical data and ends with a judgment that goes beyond that data. A judgment that goes beyond empirical data is either a hypothesis regarding future events based on a series of repetitive data, or a generalization regarding such a series of data. In this respect, inductive logic and statistics do not differ from each other. Qualitative research is used to generalize understanding of occurring phenomena [41].

Qualitative research is not presented in numbers (in quantities) but concerns the characteristics of the phenomena studied. They focus on identifying facts, measuring data, and most often answer questions; what, how much, how strongly, how often, in what part. Qualitative data analysis is a complicated process because there is no single model for qualitative research. Respondents express their views and opinions without imposing variants of answers [42]. Qualitative methods enable obtaining empirical data, and on their basis it is possible to interpret and generalize in management sciences. Observation and interviews have the greatest potential among qualitative methods in the context of obtaining source data and revealing the truth about occurring phenomena [36]. Qualitative research is the domain of the interpretative trend and is used in the context of little-known research problems. The description of phenomena can be made using models in which probabilistic methods will be used. For probabilistic models, random functions are used. Probabilistic models reflect the randomness of the phenomena that surround us. Probabilistic methods and probabilistic optimization methods can have several applications in many scientific areas, such as business management, finance, IT [24, 43, 44]. The scheme of idea of induction model is shown at the Figure 2. 


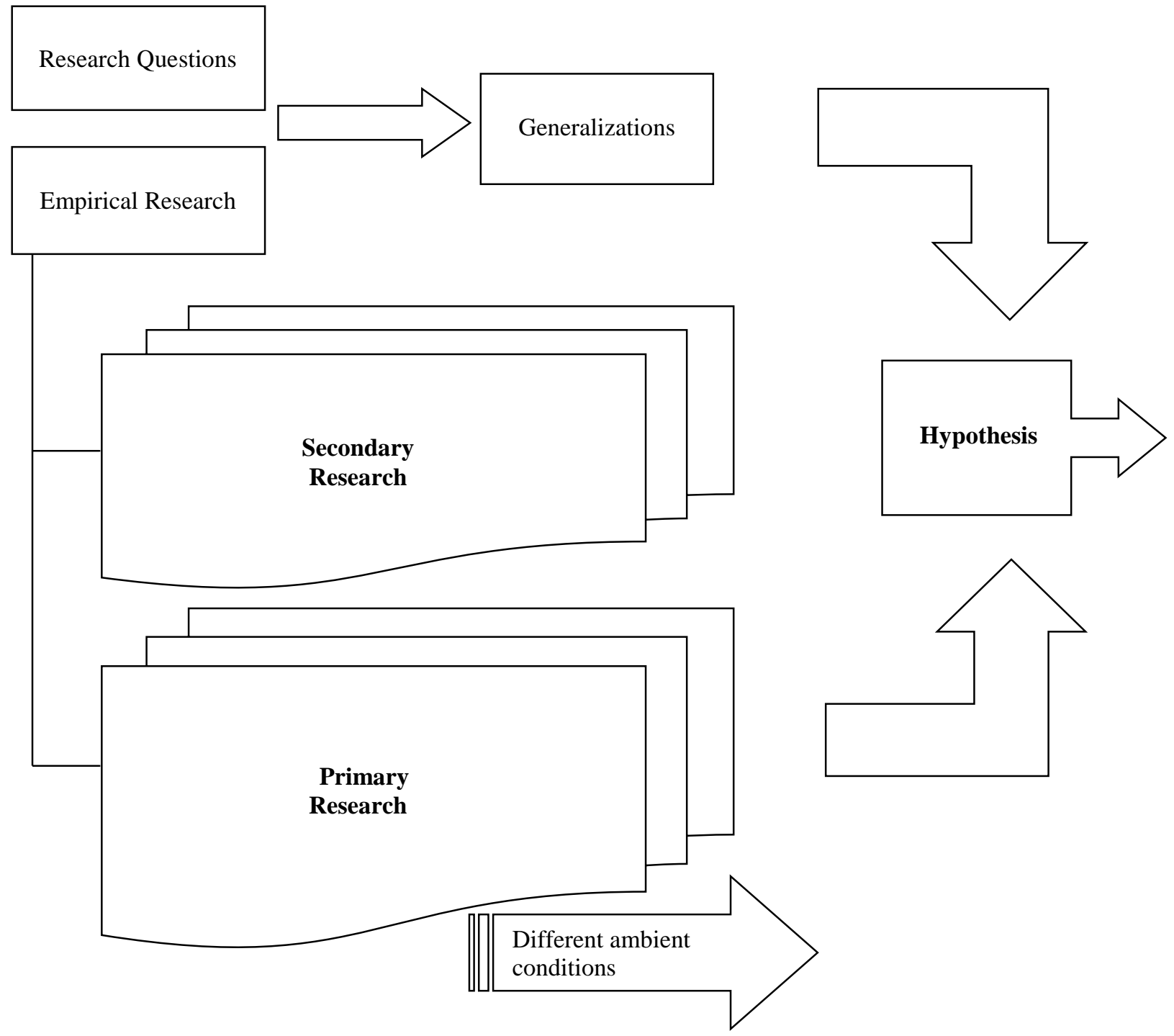

Figure 2. Induction model

At the Figure 2 secondary research mainly means an analysis of published materials and a critical review of the literature on the subject, while primary research means completed interviews, conducted reconnaissance and own observations.

\subsection{Quantity Research Method}

However, in quantitative research for which the main characteristic element are hypothetical-deductive models, theoretical foundations are first identified [45]. The theoretical foundations are built on the basis of a literature review and its critical analysis to determine the conceptual framework of the study by defining the concepts precisely. The hypothetical-deductive method, also known as the empirical science method, is an empirical research instrument [40, 45]. Using this method, theorems are obtained only to some extent likely because they are only to some extent confirmed by the facts and events collected. The hypothetical-deductive method consists in deriving logical consequences from the assumptions made and hypotheses. The conclusion follows from the premises under some logical law (scheme). The direction of inference - from the premise to the conclusion - coincides with the direction of the result (from reason to succession and thus the premises are right, and the conclusion - a consequence in deductive reasoning). The deductive system can be considered as a set consisting of sentences taken without proof (axioms), and sentences adopted on the basis of evidence whose premises are either primary statements or their consequences. Hypothetical-deductive methods are based on two assumptions: (1) all statements in science are hypothetical and revocable, and (2) the purpose of scientific proceedings is to eliminate false hypotheses [46]. Using the quantitative approach, the qualitative approach is refined and thus becomes more objective. The quantitative approach in management sciences is based on statistics. The scheme of idea of hypothetical-deductive model is shown at the Figure 3 . 


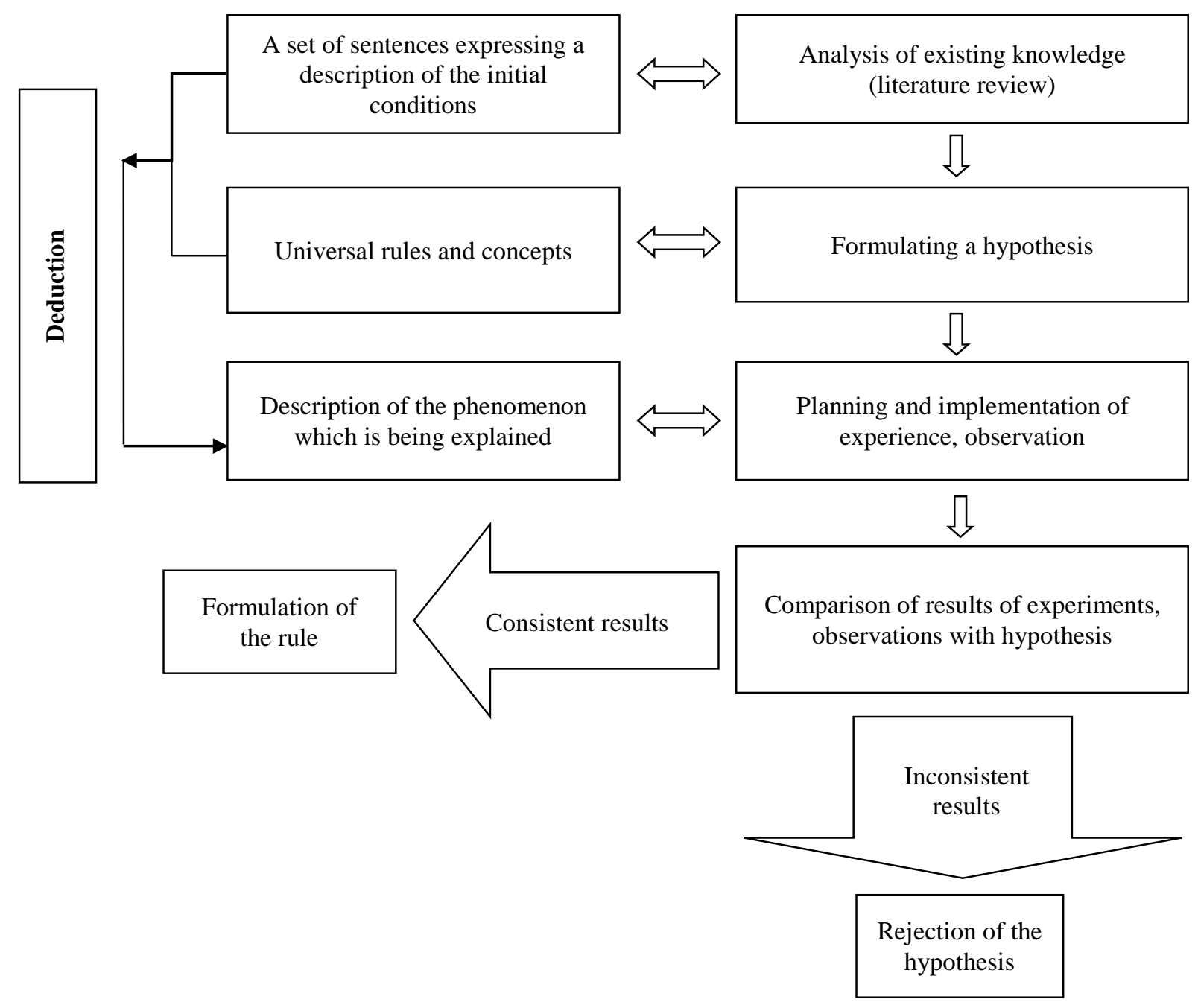

Figure 3. Hypothetical-deductive model

In the conducted research, elements appearing at the Figures 2 and 3 were implemented

\section{Results of Qualitative Research}

\subsection{Qualitative Research Realized According to the Induction Model}

Qualitative research was carried out on the basis of interviews with enterprises operating on the energy market. Research began with the construction of an induction model of individual phenomena occurring in the functioning of energy enterprises and obtained as a result of observations. The specific observed phenomena allowed for generalizations concerning adaptability. The induction model helped lead to the formulation of the theory, which in turn became a contribution to the construction of the hypothetical-deductive model, which allowed it to be tested and verified, so that the relationship with the theory became iterative-cyclical. In the conducted research, research questions were asked about the factors affecting adaptation and questions about the directions of adaptation. The induction model used in the study consisted of interviews, observations and then the formulation of general conclusions and establishing regularities based on the analysis of empirically identified phenomena and occurring processes. In the induction model, conclusions were made based on the details of the general properties of phenomena around energy companies. In the first phase of research, information on phenomena and processes was collected and the focus was on the scientific description of individual facts. The facts collected during the observation constituted the basis for inductive reasoning. The collected facts have been characterized and described as structural and causal analysis.

\subsection{Research Questions}

During the interviews, a structured questionnaire with questions was used, in which the relations between the enterprise and its macro-environment were referred to. The macro-environment was understood as a whole consisting of individual elements called environment: political environment, economic environment, ecological environment, 
legal environment, technological environment. Macro-environment is the type of external business environment in which the firm and its forces exist, which gives opportunities or pose threats to the firm $[47,48]$.

1. What elements of the environment have a significant impact on business development?

2. Does the size of the enterprise influence the intensity of taking into account the legal environment?

3. Which macro-environment changes are the most difficult to adapt by the company?

4. Which elements of macro environment affect adaptation decisions?

5. Are there problems with the adaptation of the enterprise to legislative changes?

6. How do companies assess the importance of adaptation strategies?

7. Do and how often do companies monitor the environment to keep abreast of various market events?

\subsection{Text Analysis}

As secondary research, desk research was based on literature published in English and Polish languages as well as reports and articles published in specialist press (e.g. International Energy Agency, Energy-World Bank Group). As part of desk research, content analysis, analysis of existing statistical data and historical and comparative analysis were carried out. Moreover an analysis of the data contained in the annual reports of energy enterprises was carried out, and besides an analysis of data coming from other literature items and specialist magazines as Energy Manager Magazine, Energy Future, Control Engineering, Harvard Business Review and others.

\subsection{Primary Research (Empirical Research - Interview)}

Interviews were realized in the group of managers and directors of the energy companies. During interviews it was possible to obtain information thanks to which it was easier and better to understand the analyzed phenomena. Interviews have brought out knowledge and opinion on adaptability. Main questions about the company's development and strategy were asked during the interview.

What is your vision for the company? What changes, if any, would you make to the strategic direction?

What do you see as the key macro-trends (macro environments), regulatory changes, and industry structures across the businesses in the energy sector?

What changes, if any, would you make to the strategy and board processes?

Would you make any changes to the key corporate processes, such as adaptation to the market, budgeting, planning, risk reviews, or business reviews? Why?

\subsection{Observations}

Observations consisted of making systematic insights in a planned and intentional manner. Observations allowed to notice and record unexpected events. The observation on the group of energy enterprises was a precisely planned activity, they had a clearly defined goal and structure of proceedings, thanks to which they were not accidental. Thanks to this approach, distortion in the observation process could be avoided. The information collected during observation helped to find answers to specific research questions previously asked. The observations made allowed to analyze detailed solutions used by specific enterprises. The essence of the observation method was to qualitatively capture the causes, course and effects of specific phenomena and decisions made.

\subsection{Generalizations}

On the basis of conducted interviews and observations, generalizations were formulated. The synthesis carried out in the phenomena and processes under investigation allowed to present the leading functions of the proposed solution in a new approach. Enterprises adapt their activities to the requirements of the environment. Depending on the size of the enterprise, they follow different ways to adapt to the environment. Elements of the environment influence decisions in different ways. Managers are looking for new, innovative solutions and bear the costs associated with the R\&D sphere.

The observations were carried out based on the PESTEL analysis, which allowed the grouping of individual components associated with adapting to the requirements of the environment and was the basis for observation. The PESTEL is acronym of the first letters of words: political, economic, social, technological, ecological and legal elements of macroeconomic environment [49]. The PESTEL analysis is a method used to study the macroeconomic environment of the enterprise. It consists in describing the impacts of individual areas (mentioned above) of the environment on a given company $[50,51]$. It is otherwise called general segmentation of the environment. 
The experimental simplified inductive research model was adopted in the paper, which allowed to visualize the variables under examination and to show their interdependence. The relationships that arose between individual variables formed the basis for formulating generalizations. Independent variables were separated and then a static model was built. The static model, taking into account the impact of individual independent variables on dependent variables, is presented in Figure 4. Dependent variables in the research model were the result and changed depending on the impact of independent variables. Independent variables in the study were subject to actions and changes to determine their impact on dependent variables. The research model used in this study, describing the functioning of enterprises on the electricity market, is presented in Figure 4.

\section{Independent variables}

\begin{tabular}{|c|}
\hline $\begin{array}{c}\text { Legal environment } \\
\text { Liberalization } \\
\text { Control }\end{array}$ \\
\hline Economic Environment \\
\hline Social Environment \\
\hline Technological environment \\
\hline Ecological environment \\
\hline Political environment \\
\hline
\end{tabular}

Dependent variables

Basic relationships
Adaption Strategy

Active adaptation (anticipatory, innovative)

Passive adaptation (reactive, conservative)

Figure 4. Relationship between variables in the hypothetical-deductive research model

Analytical induction generated a set of hypotheses that are relationships between concepts and treated as a set of hypotheses subject to constant verification. Relations and interactions between environmental factors of macroenvironment.

\subsection{Formulating a Hypothesis}

The research assumed the hypothesis that energy companies adapt to the environment (passive adaptation) and, depending on the size of the company, they start cooperation with the environment (active adaptation). Energy companies that adapt their activities to the environment in a passive manner they apply the approach called passive reactive adaptation (conservative). Energy companies that have entered the path of active adaptation begin cooperation with market regulating institutions, implement innovative solutions in advance, anticipate upcoming market events or shape them and become active players. This approach can be described as active - anticipative adaptation (innovative).

\subsection{Elements of the Environment}

To perform the above analysis of energy companies against the background of the environment, the best suited due to its simplicity and universal nature - PESTEL analysis ( P - Political, E - Economic, S - Social, T Technological, E - Environmental, L - Legal). Individual elements are independent variables. The PESTEL analysis consists in examining and sometimes forecasting the segments of the organization's environment: political environment $(\mathrm{P})$, economic and demographic environment $(\mathrm{E})$, social environment $(\mathrm{S})$, technological environment $(\mathrm{T})$, environmental environment (E) and legal environment $(\mathrm{L})$. The essence of this tool is to define the basic spheres of the environment, i.e. those areas that can have a key impact on the functioning of the enterprise and its future strategy. The purpose of PESTEL analysis is to determine the factors that most strongly affect the activities of a given enterprise or group of organizations. The PESTEL analysis has a wide set of tools to assess the competitiveness of regions, industries, and individual organizations [51-53]. These are three groups of tools: tools for analyzing the environment of the enterprise (sector) and its impact on the situation of the examined entity, tools examining the competitiveness of a given entity and tools for strategic positioning, i.e. showing the examined object against the background of external conditions. The PESTEL analysis for the energy sector lists individual components that significantly constitute the elements of a given environment and have an impact on dependent variables. The matrix of PESTEL elements is shown at the Table 1. 
Table 1. Elements shaping individual environments

\begin{tabular}{|c|c|}
\hline Political environment (P) & Economic environment (E) \\
\hline $\begin{array}{l}\text { EU policy; state policy; government programs; departmental programs; } \\
\text { positions and decisions of institutions and public administration } \\
\text { offices, e.g. the Energy Regulatory Office (ERO), the Office of } \\
\text { Competition and Consumer Protection (CCP) and the European } \\
\text { Commission; control system; consumer protection; bureaucracy; } \\
\text { control / deregulation; EU ETS emissions trading policy; support for } \\
\text { renewable energy sources; tax breaks; the foreign policy; international } \\
\text { agreements. }\end{array}$ & $\begin{array}{l}\text { Interest rates, exchange rates affecting the valuation of assets and } \\
\text { liabilities of the enterprise, labor costs; inflation; fiscal policy, } \\
\text { monetary policy; tax policy; unemployment rate; business cycle stage; } \\
\text { economic growth and energy demand; electricity prices on the } \\
\text { wholesale market; electricity and coal sales prices and distribution } \\
\text { tariffs; prices of certificates of origin for energy from renewable } \\
\text { sources and from cogeneration. }\end{array}$ \\
\hline Socio-cultural and demographic environment $(S)$ & Technological environment (T) \\
\hline $\begin{array}{l}\text { Ecological awareness of the society; health awareness, family social } \\
\text { structure, level of wealth; attitudes towards saving and investing; age } \\
\text { structure; aging population; population growth rate, migration rate; role } \\
\text { of shareholders; }\end{array}$ & $\begin{array}{l}\text { Infrastructure level; access to innovative solutions; development and } \\
\text { automation; technologies enabling reliability of energy supply and } \\
\text { energy security; economy demand for innovation; pace of } \\
\text { technological change; modernizations and modifications; energy } \\
\text { production, transmission and storage. }\end{array}$ \\
\hline Environmental - ecological environment (E) & Legal environment (L) \\
\hline $\begin{array}{l}\text { Climate warming; climatic conditions reduction of greenhouse gas } \\
\text { emissions; proper exploitation of limited natural sources; waste } \\
\text { management; energy conservation; sensitivity to environmental } \\
\text { protection; reduction of environmental load; }\end{array}$ & $\begin{array}{l}\text { Legal regulations; tax law; commercial law; environmental protection } \\
\text { law; legislative changes regarding enterprises, intellectual property } \\
\text { rights; patents; antitrust law; electricity generation support systems, } \\
\text { legal regulations regarding EU ETS emissions; legal barriers; customs } \\
\text { barriers, restrictions; trade regulations. }\end{array}$ \\
\hline
\end{tabular}

\subsection{System Approach to Adaptability}

System approach in management sciences means joint management of related processes, which should contribute to increasing the efficiency and effectiveness of the enterprise in achieving its goals [54, 55]. In particular, the detailed requirements in the system approach to enterprise management relate to: defining the system through processes and their goals, detailing the goals in such a way as to achieve them in an effective manner, improving the system through research and monitoring, and testing the availability of resources [56]. The system can therefore be defined as a set of related elements functioning as a whole [57]. The system is a separate part of reality for which you can specify the entry and exit limits and internal processing processes. The system should perform adaptive, transformation and development functions [58]. The main tasks of the organization management system include identifying the causes of non-compliance in processes and preventing disruptions and errors in the functioning of individual areas of activity. Such a broadly defined system includes both processes directly related to monitoring and improvement, as well as those having a direct impact on the effects of the organization. Depending on the particular change under consideration, a single system can be both flexible and adaptive. An example of a system with a high degree of adaptation are people who constantly use their psychomotor, intellectual and sensory / perceptual abilities to change themselves [59].

Adaptation in the systemic approach can be presented as a dynamic model with feedback, where legal regulations and various elements of the political and legal environment constitute a "control device", while the enterprise is a "control object" which may be affected by various interfering signals in the form of variable macro environment. The scheme of adaptation with feedback is presented at the Figure 5.

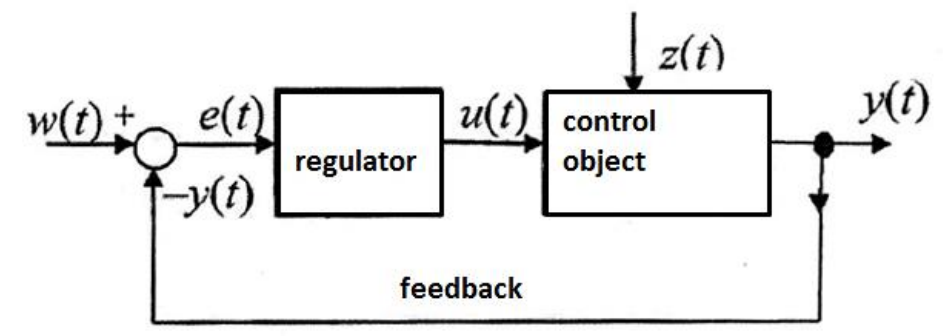

Figure 5. Dynamic adaptive model in terms of the system. Adaptation as a feedback system

Where:

$\mathrm{w}(\mathrm{t})$ - signals from the environment, state interference;

e (t) - input signals (law, directive, act);

$\mathrm{u}(\mathrm{t})$ - regulatory stimulus (ordinances and regulations, e.g. ERO); 
$\mathrm{z}(\mathrm{t})$ - interference, signals from the environment affecting the enterprise (sector);

$y(t)$ - enterprise response, adaptation to the signal given by the environment;

$[-y(t)]$ - feedback, response, self-regulation.

There are a set of factors that limit or slow down changes in an organization. Enterprises experience a significant impact of various internal factors, e.g. rules governing the functioning of the organization and the impact of environmental factors, e.g. the legislative process or the organization's activities in the social system [60], which causes inertia in the process of adapting and adapting to the new (changing) environment. Organizational inertia is often treated as pathology. A high level of inertia can cause a significant lack of agreement between the organization's results and expectations related to adapting to the conditions of a changing environment. In the aspect of the change process, the strength of inertia may vary depending on the life cycle stage, its size and complexity and dynamic capacity can be a tool to increase their competitiveness [61, 62]. However, inertia can also have positive features for enterprises that too willingly adapt to the constant changes arising from the turbulent, rapidly changing environment [63]. As demonstrated by Hannan and Freeman (1984) [64], the worst of all possible situations is the constant change of structure and continuous reorganization, after which it turns out that the company, should again switch to a new configuration, which requires another structure. Therefore, inertia has a clear advantage in situations where the environment is very uncertain, characterized by rapid changes and these changes are dramatic. Companies sometimes delay the adoption of rules set by powerful entities such as the state and other rule-setting organizations, despite the risk of slow adoption or non-compliance. As a broader contribution, we hope that this work draws attention to the company's various responses to coercion rules, a part of institutional theory that has been neglected, although it provides significant implications for the strategic choices of companies when adapting to their environment [65].

\section{Results of Quantitative Research}

\subsection{Quantitative Research Realized According to the Hypothetical-deductive Model. Analysis of Existing Knowledge (Literature Review)}

In the research on the adaptability of energy enterprises, a review of the literature on strategic management in the field of energy enterprises and directions of research carried out in this field was carried out. An integrated model was then built based on accumulated knowledge with the intention of subjecting it to empirical testing. The hypotheticaldeductive model was used in the completed research to determine the nature of features and events occurring in energy enterprises, and to find mechanisms and relationships occurring between them. A review of the literature shows that so far in the management sciences the issue of adaptation has not been discussed in detail and in the energy sector strategic management was not seen at all as an important element related to the development of enterprises. Literature analysis allows showing the current state of knowledge regarding the concept of adaptation in management sciences. Many authors described the adaptation from a specific point of view, while there was no comprehensive and comprehensive approach to this issue. Pérez-Nordtvedt et al. (2013) [66] drew attention to the temporary adaptation to the changing environment. However, the issue of implementing adaptation as a new solution in organizational culture was described by Canato et al. (2013) [67]. Magnusson et al. (2013) [68] analyze the marketing adaptation and influence for better financial results. According Eakin and Patt (2011) [69] adaptation depends also on the level of countries development and social sensitivity. Adaptation as companies self-adjust to the changing environment as a dynamic process between decision-makers and environment was described by Hatum and Pettigrew (2006) and also by Seroka-Stolka et al. (2016) [70, 90]. Adaptation as a survival strategy for SME was analyzed by Andries and Debackere $(2006,2007)$ [71, 72]. The adaptation of enterprises to a new environment was the subject of research by Rutherfor et al. (2010) [73]. Opportunities and threats as drives for adaptation were the topic of research realized by Saebi et al. (2017) [74]. A critical analysis of the literature shows that it is worth undertaking in-depth research on adaptability in the energy sector.

In Polish science, Garbara was a pioneer in thinking about adaptation, then called the adaptation process. He also distinguished active or passive adaptation of the organization to the environment [75]. The importance of adaptation for enterprise development has also evolved over the last several years [76]. At the beginning, the concept of adaptation was formulated as continuous, dynamic adaptation to a changing, uncertain environment as well as proper and proper management of internal interdependencies [77]. Then, Ogunmokun and Li (1999) found that full adaptation is very rare in strategic management of an enterprise. Companies very often adapt and modify only selected fragments of their business activities [78]. Chakravarthy (1982) [76] defined adaptation as the ability to survive an enterprise in its environment [79], while Andries and Debackere (2007) emphasized that the ability to adapt to new conditions allows the company to survive in the market and even move towards becoming a leader [72]. Scott and Davis (2015) [91] postulated that each organization operates in a specific technical, social, cultural, legal environment to which it should adapt. The beginning of the 21 st century is a look at adaptation strategies as a factor that mobilizes an enterprise to be active in the new reality. Adaptations began to be perceived as an opportunity to use the opportunities emerging on the market and strive to gain a competitive advantage - at this point one can see the beginning of the view 
on adaptation as an active, anticipatory strategy. For enterprises seeking opportunities to operate on the market in a new reality and trying to take advantage of various opportunities, adaptability may become a factor of competitive advantage. In the energy sector, one example of a new reality could be action in e-energy i.e. digitalization, smart grid, information and communication technologies, very often created as innovative startups [80, 81]. The ability to adapt and the dynamics of adaptive changes that are implemented by decision makers in the enterprise show their managerial abilities [82]. Integration with other industries e.g. with IT industry, will strengthen the technological level. Managers should implement the strategy to cooperate with the changing market in an effective and successful manner. In order to succeed, they should understand how changes within the organization affect its functioning and then make changes that will allow the company to adapt to the new, changing market situation [83]. Then Manolova et al. (2007) and Sánchez et al. (2011) [92, 93] described adaptations as (1) the company's ability to develop the right direction of strategy and structure as well as internal relations and organizational culture in order to build a strong market position, and (2) the ability to face or even influence the external environment. Moreover organizational culture resulting from national traditions may affect the effectiveness of operational strategies and implemented activities [84].

\subsection{Formulating Hypotheses}

The aim of quantitative research was to prove the truth or falseness of hypotheses formulated in them. In the case of quantitative research, research hypotheses were made to check and justify phenomena related to adaptability. The hypotheses were a guess about reality and they were checked by comparing the real state with the hypothetical one. The verification of hypotheses served to check whether a given opinion on adaptability should be adopted or whether it should be rejected. The following hypotheses were made in the research:

1. Elements of macro environment have a significant impact on business development

2. The size of the enterprise influences the intensity of taking into account the legal environment

3. Some elements of the macro environment pose difficulties in the adaptation process

4. Legislative changes are a problem in the adaptation process

5. Enterprises recognize the importance of adaptation strategies

6. Enterprises monitor the environment to keep abreast of various market events

\subsection{Surveys and Telephone Interviews}

Selected energy companies with concessions in the field of generation (production service), transmission service and distribution service and sales service of energy belonging to the highly regulated sector were tested. In the first stage, 145 companies belonging to the broadly understood energy sector from all over Poland were included in the survey, classified according to the Polish Classification of Activities (PKD) to group 35.1 (production, transmission, distribution, trade services), while the second verification stage was carried out on selected enterprises from individual groups according to the PKD division and on company size. The surveyed companies were divided in terms of the number of employees into three basic groups (in accordance with Journal of Laws 2004 No. 173 item 1807 and in accordance with Commission Regulation (EC) No. 800/2008 of August 6, 2008): micro, small enterprises and large enterprises. The research was carried out in two stages: the first stage on a group of 145 companies and the second stage on a group of 14 companies. The first stage of the research was carried out in the form of a questionnaire, while the second stage of the research was carried out in the form of Telephone-Depth-Interviewing in order to compare previous results and identify possible new directions of enterprise development. The second stage of the research allowed to compare the situation of enterprises with the situation presented in the answers given in the first stage of the research and confirmed that companies are still implementing adaptation strategies.

\subsection{Findings}

The results of the conducted surveys show that in most enterprises, both micro, small and large, the impact of legislative and political elements of Poland and the EU on strategic decisions is considerably taken into account.

At the Figure 6 we can see the elements of the environment which play pivotal role and less important role in the decision making process. 


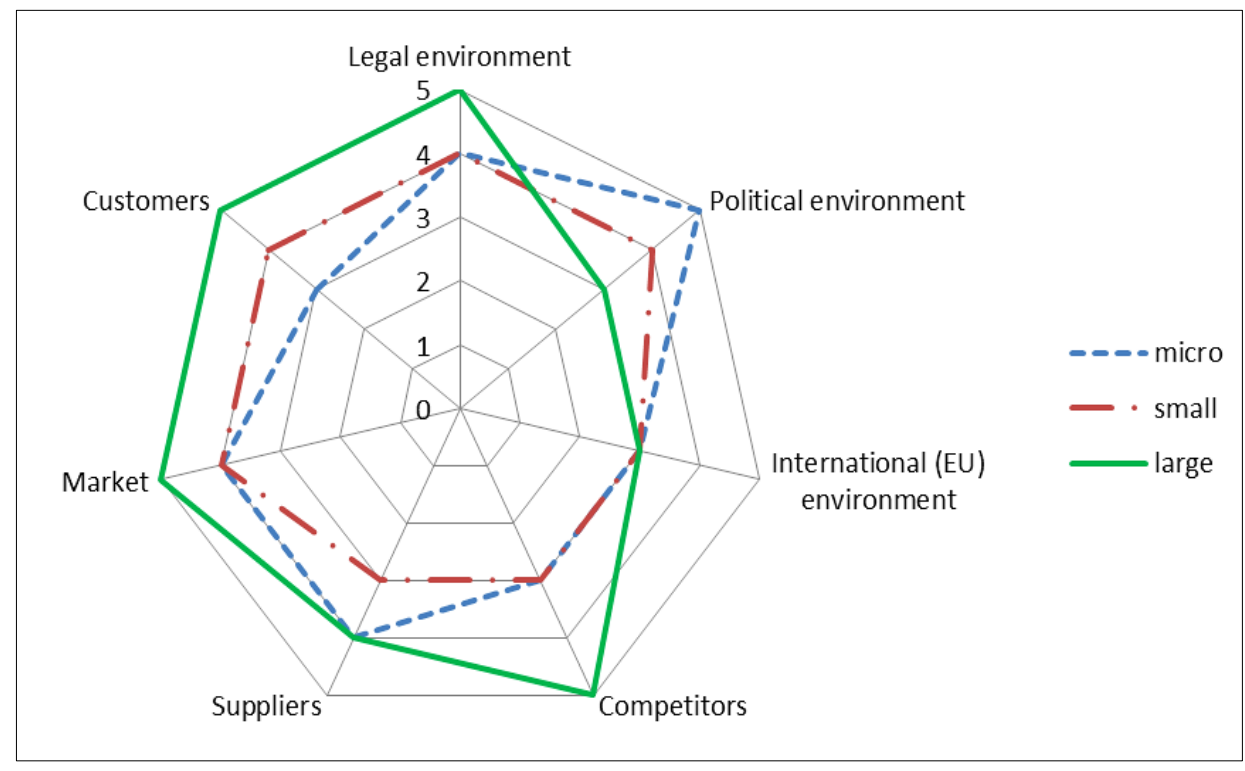

Figure 6. Elements of the environement which has influence on the companies

Legal, political and international environment has influence on decision making process and companies take under consideration those environments. From the Figure 7 we can observe that intensity of influence depends on company size.

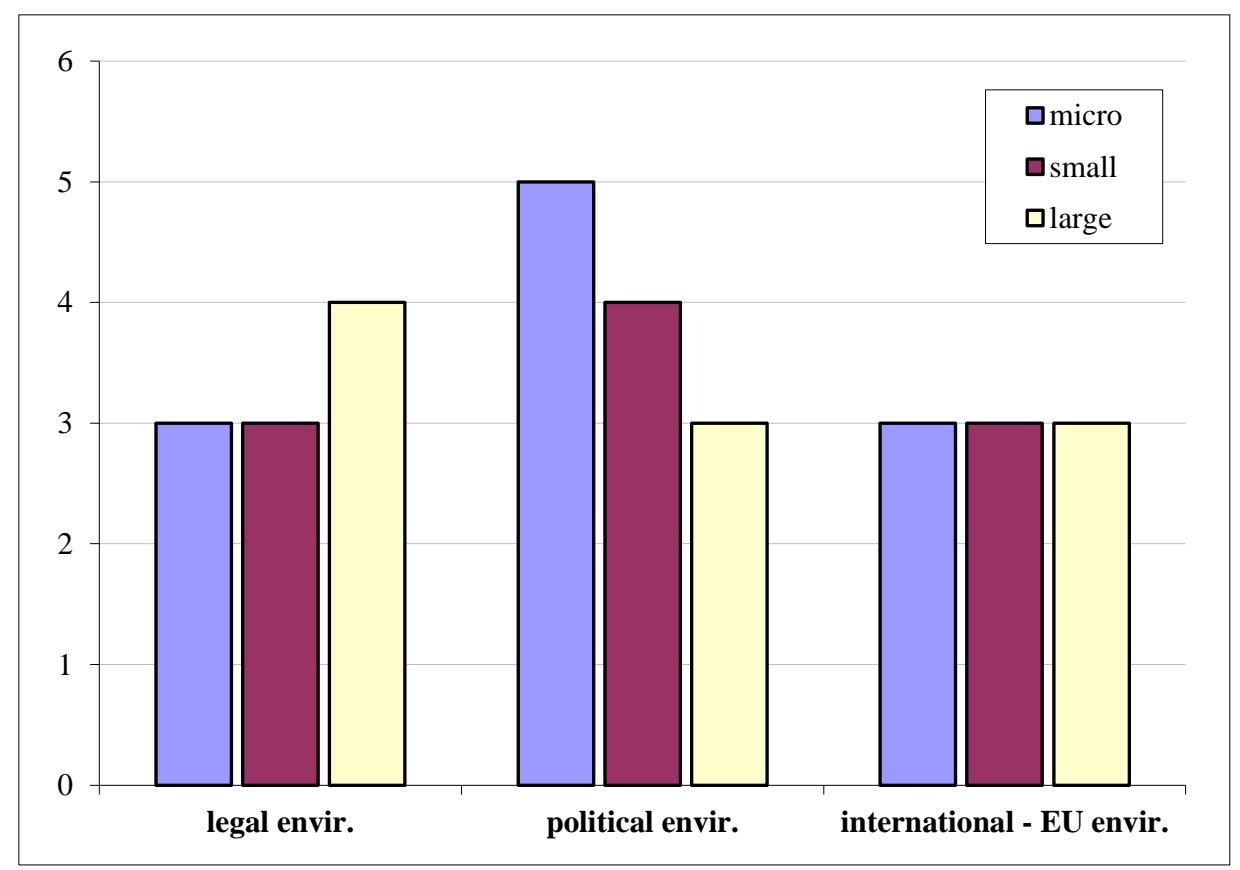

Figure 7. Intensity of legislative and political factors

Figure 7 shows that power companies quite highly assess the impact of the national and EU legal and political environment on the actions taken - grades were given from 3 to 5 .

Market research is a set of analyzes aimed at learning about market phenomena, factors and processes (including their genesis, current state and development trends - opportunities and threats) on the basis of which companies can formulate the most favorable current and planning decisions and build a development strategy. Market research concerns market analysis. Their goal is to learn about the situation on the market and to determine the company's share in this market and achieve knowledge about competitors. Frequency and regularity in carrying out market research regarding changes, the appearance of various occasions or the behavior of competitors are one of the conditions for rapid response and proper operation of enterprises. A quick response to emerging opportunities and threats gives the company the chance to adopt its strategy to market requirements. Due to the frequency and repeatability of market research, we can divide into two main types: continuous and periodic research. Continuous tests are conducted on a given sample continuously for some time. Periodic examinations are carried out on a given sample every certain time 
in advance. In this way we can determine the degree of response to a given factor. Of the large number of energy enterprises belonging to the group of micro and small enterprises, market observations and surveys are carried out once a year (periodic research), although there is also a large group of micro enterprises which regularly monitors the market - every day and this can be considered as continuous research. There is also a group of small companies which observe the market once a week. However, large companies regularly carry out market observations once a month [8589]. Another issue related to conducting market research and observing it is the issue of financial expenditure allocated for this purpose. After analyzing the problem, it is possible to observe differences in the frequency depending on the size of the enterprise. Large companies plan market research budgets for the next year in advance, while small enterprises make decisions depending on the availability of free funds. A small company is not able to carry out professional large market research alone because it is now a vast and highly specialized field of knowledge, and even large companies that once had their own research departments are now also outsourcing. At most, a small company can carry out a preliminary market investigation. This point of view regarding the financing of market research is an extension of previous research from 2019. The issue of market research and its financing in a group of companies is shown in Figure 8.

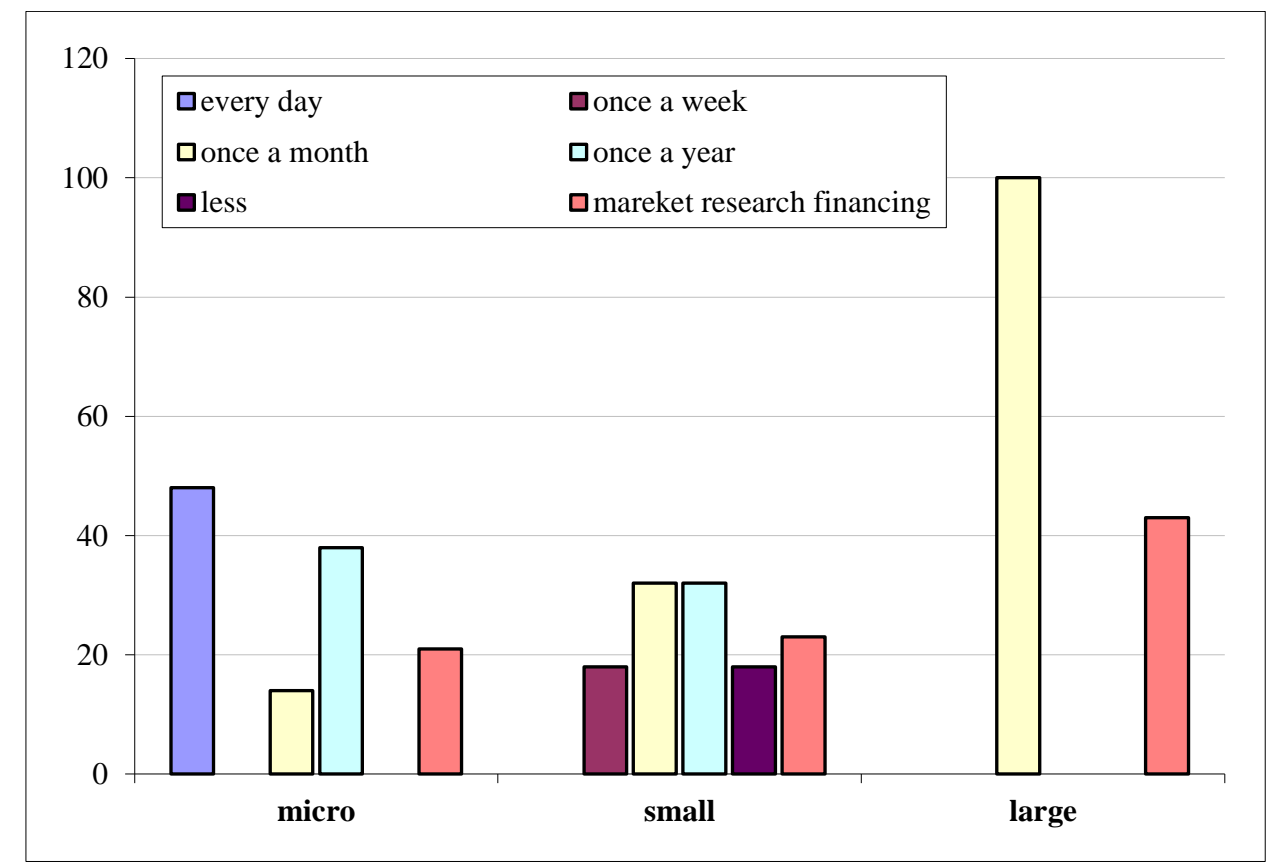

Figure 8. Issue of market research and its financing

In the group of enterprises surveyed, the financing of market research is twice as high in large companies as in micro and medium companies, which is undoubtedly due to the high costs of the market research.

Energy utilities, which operate in a prosper industry based on modern technology and solutions, must closely monitor and observe their surroundings, make market research. Constant monitoring of change is one of the conditions for a quick response and proper action by businesses under the influence of emerging opportunities and threats. In the group of big companies all respondents indicated one answer, that monitoring is conduct once per month. Large companies carry out monthly market surveillance. It shows that in the big companies perhaps functioning similar rules, which regulate this activities. The situation in the groups of micro and small enterprises is totaling different. Among the numerous number of power companies belonging to the micro and small business group, the market is monitored and surveyed once a year. There is also a large group of microenterprises that monitors the market systematically every day. Among the group of the small companies, there are firms which carried out market observations every day and also less than once per year. Heterogeneous answers in the group of micro and small enterprises are the basis for wondering whether there is any relationship between the frequency of market research conducted and the size of the enterprise. In order to analyze if there are dependencies in frequency of market monitoring in the group of micro and small enterprises, the test chi-square $\left(\chi^{2}\right)$ were realized. But as an extension of the research carried out by Borowski in 2019, V-Cramer analysis was also carried out.

Null hypothesis: Assumes that there is no association between market frequency and size of enterprises.

$\chi^{2}=\sum_{i=1}^{n} \frac{\left(O_{i}-E_{i}\right)^{2}}{E_{i}}$

Where; $O_{i}$ : Observed value, $E_{i}$ : Expected value. 
Example of Expected value calculation for size (micro, small) and frequency (every day,..., less) is shown in the Table 2, while results of expected value is shown in the Table 3.

Table 2. Matrix of expected value

\begin{tabular}{ccc}
\hline & S1 (micro) & s2 (small) \\
\hline $\mathrm{f}_{1 \text { (every day) }}$ & $\mathrm{n}_{11}$ & $\mathrm{n}_{12}$ \\
$\mathrm{f}_{2 \text { (once a week) }}$ & $\mathrm{n}_{21}$ & $\mathrm{n}_{22}$ \\
$\mathrm{f}_{3 \text { (once a month) }}$ & $\mathrm{n}_{31}$ & $\mathrm{n}_{32}$ \\
$\mathrm{f}_{4 \text { (once a year) }}$ & $\mathrm{n}_{41}$ & $\mathrm{n}_{42}$ \\
$\mathrm{f}_{5 \text { (less) }}$ & $\mathrm{n}_{51}$ & $\mathrm{n}_{52}$ \\
\hline
\end{tabular}

$\mathrm{E}=(56 \times 117) / 137=48$ (micro company, every day)

$\mathrm{E}=(21 \times 117) / 137=18$ (micro company, once $\mathrm{a}$ month)

$\mathrm{E}=(21 \times 20) / 137=3$ (small company, once per month)

Table 3. Results of expected value

\begin{tabular}{|c|c|c|c|c|c|c|}
\hline & & \multicolumn{5}{|c|}{ Size of enterprise } \\
\hline & & \multicolumn{2}{|c|}{ Micro } & \multicolumn{2}{|c|}{ Small } & Total \\
\hline & & $\mathrm{O}$ & $\mathrm{E}$ & $\mathrm{O}$ & $\mathrm{E}$ & \\
\hline \multirow{6}{*}{$\begin{array}{l}\text { Frequency of market } \\
\text { monitoring }\end{array}$} & Every day & 56 & 48 & 0 & 8 & 56 \\
\hline & Once a week & 0 & 5 & 6 & 1 & 6 \\
\hline & Once a month & 15 & 18 & 6 & 3 & 21 \\
\hline & Once a year & 46 & 43 & 4 & 7 & 50 \\
\hline & Less & 0 & 3 & 4 & 1 & 4 \\
\hline & & 117 & 117 & 20 & 20 & 137 \\
\hline
\end{tabular}

In our research number of micro enterprises was 117 and number of small enterprises was 20 . Totally in the group of micro and small 137 companies were investigated.

Alpha level of significance $(0.05)$, and our case degrees of freedom df $=(c-1) *(r-1)=(2-1) *(5-1)=4$

Where $\mathrm{c}$ - column; $\mathrm{r}$ - row. The theoretical $\chi^{2}$ distribution depending on alpha level of significance and degree of freedom is shown in the Table 4.

Table 4. Theoretical $\chi^{2}$

\begin{tabular}{cccccccccc}
\hline \multicolumn{7}{c}{ Alpha level of significance } \\
\hline $\mathbf{d f}$ & 0.20 & 0.10 & 0.05 & 0.025 & 0.02 & 0.01 & 0.005 & 0.002 & 0.001 \\
$\mathbf{1}$ & 1.642 & 2.706 & 3.841 & 5.024 & 5.412 & 6.635 & 7.879 & 9.550 & 10.828 \\
\hline $\mathbf{2}$ & 3.219 & 4.605 & 5.991 & 7.378 & 7.824 & 9.210 & 10.597 & 12.429 & 13.816 \\
$\mathbf{3}$ & 4.642 & 6.251 & 7.815 & 9.348 & 9.837 & 11.345 & 12.838 & 14.796 & 16.266 \\
$\mathbf{4}$ & 5.989 & 7.779 & $\mathbf{9 . 4 8 8}$ & 11.143 & 11.668 & 13.277 & 14.860 & 16.924 & 18.467 \\
\hline $\mathbf{5}$ & 7.289 & 9.236 & 11.070 & 12.833 & 13.388 & 15.086 & 16.750 & 18.907 & 20.515 \\
$\mathbf{6}$ & 8.558 & 10.645 & 12.592 & 14.449 & 15.033 & 16.812 & 18.548 & 20.791 & 22.458 \\
\hline $\mathbf{7}$ & 9.803 & 12.017 & 14.067 & 16.013 & 16.622 & 18.475 & 20.278 & 22.601 & 24.322 \\
\hline
\end{tabular}

In our case empirical $\chi_{\text {emp }}^{2}=56,32$ and is higher than theoretical $\chi_{\text {theor }}^{2}=9,48$, so null hypothesis was rejected. There is association in the decision process concerning the frequency of market analysis in the group micro and small enterprises.

As mentioned in the article, the chi square test informs about the existence of dependence, while the test itself does not tell us about the strength of the relationship. In order to check whether the correlation is strong or weak, a contingency factor was used. In the case of multi-divisive tables that appear in our research, the V-Cramer coefficient was used. One final $\chi^{2}$ chi square based measure of association that can be used is Cramer's V. Once the $\chi^{2}$ chi square value has been calculated, the determination of $\mathrm{V}$ is relatively straightforward. This measure is defined as contingency coefficient. 
$V=\sqrt{\frac{\chi^{2}}{n(m-1)}}$

Where: V: Cramer Coefficient, $\chi 2$ : Result of chi square test, $\mathrm{n}$ : Number of observation, and m: The smaller of the $\mathrm{c}$ and $\mathrm{r}$ numbers specifying the number of columns and rows.

Cramer's V equals 0 when there is no relationship between the two variables, and generally has a maximum value of 1 , regardless of the dimension of the table or the sample size. In our case $\mathrm{V}=\left[9.48^{2} / 137(2-1)\right]^{1 / 2}=0,8$

We can conclude that there is quite strong relationship between our variables.

Another important issue was the perception of adaptation by energy companies. The adaptation strategy is an important way of developing enterprises; however the level of perception of the significance of adaptation strategies depends on the size of the enterprise. The issue of adapting the enterprise to the environment is also concerning its involvement in the field of research and development $(\mathrm{R}+\mathrm{D})$. "Research and development" actions of the companies can rely on internal or external activities. Depending on the size of the company, there is a difference in the number of companies carrying out research on their own or by outsourcing. The research results are shown in Figure 9.

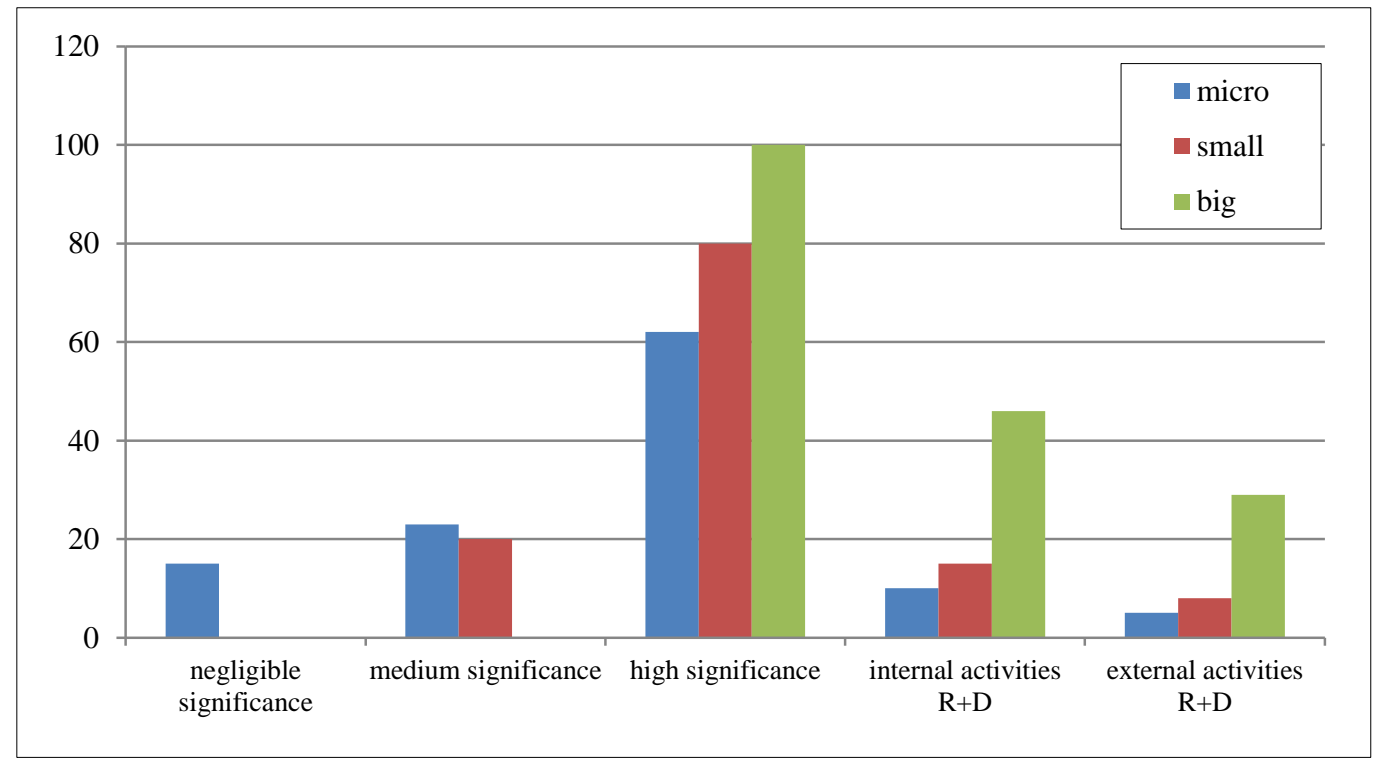

Figure 9. The importance of adaptation strategies in the energy sector and $R+D$ activities

Research results on the importance of adaptation are presented in Figure 9 and it follows that all enterprises recognize the important role of adaptation. As the size of the enterprise changes, the approach to the importance of adaptation strategies in company development changes. For large enterprises, the adaptation strategy plays an important and crucial role, while in the group of micro-enterprises over $60 \%$ recognize the importance of adaptation.

In order to indicate the relations between size of the company and their macro and microenvironment as well as internal, external activities R+D (expanding research from 2019), the Pearson Correlation was calculated. Pearson Correlation was used in the statistical analysis of variables. The Pearson Correlation is a measure of the linear correlation between two variables $\mathrm{x}$ and $\mathrm{y}$. Variable $\mathrm{x}$ in or case is the size of the company and variable $\mathrm{y}$ is the influence of macro- and micro- environmental factors. A value of coefficient is between 1 and -1 , where 1 is completely positive linear correlation, 0 is no linear correlation, and -1 is completely negative linear correlation. The Pearson Correlation Coefficient (PCC) was calculated using the Equation 3:

$r_{x y}=\frac{\sum\left(x_{i}-\bar{x}\right) \sum\left(y_{i}-\bar{y}\right)}{\sqrt{\sum\left(x_{i}-\bar{x}\right)^{2}} \sqrt{\sum\left(y_{i}-\bar{y}\right)^{2}}}$

Where; $r$ is the correlation coefficient of $x$ and $y, \bar{x}=\frac{1}{n} \sum_{i=1}^{n} x_{i}$ denotes the mean of $x$, and $\bar{y}=\frac{1}{n} \sum_{i=1}^{n} y_{i}$ denotes the mean of $y$. The coefficient $r_{x y}$ ranges from -1 to 1 , and it is invariant to linear transformations of either variable. The coefficient of Pearson correlation for 3 groups of enterprises and elements of macro-environment are shown at the Table 5 . 
Table 5. Pearson Correlation

\begin{tabular}{cc}
\hline Coefficient of Pearson Correlation $\mathbf{p}<\mathbf{0 . 0 5} \mathbf{~ N = 3}$ (micro, small and large enterprises) \\
\hline Size of the company \\
Agencies: ERO, CCP* & 0.8660 \\
State authority & -1.0000 \\
EU authorities & -0.8660 \\
Administrative institutions & 0.8660 \\
Competitors & 0.8660 \\
Market & 0.0000 \\
Suppliers & 0.8660 \\
Customers & 1.0000 \\
Internal activities R+D & 0,1977 \\
External activities R+D & 0,0495 \\
\hline
\end{tabular}

*ERO - Energy Regulatory Office; CCP - Competition and Consumer Protection

From the Table 5 we can conclude that there is very strong negative correlation between size of company and state authorities. The big company didn't indicate the strong relations with State authorities. The larger the company, the smaller the influence of the State authorities. And opposite situation with customers, if the bigger company, the bigger is influence of the customers. However, there is no correlation in outsourcing research and development $(\mathrm{R}+\mathrm{D})$ activities or realize of these activities by own company teams.

\section{Adaptation in the Power Sector - Final Research Results and Conclusions}

Adaptation is one of the strategies used by the company. Enterprises are implementing an adaptation strategy, which, depending on the pace and type of changes, can be considered as a four-field matrix. This approach distinguishes four substrategies of adaptation as a function of organizational change: tuning, rebuilding, re-orientation and restoration. Reorientation can be seen as anticipatory changes - in this type of substrategy, changes are planned on the basis of upcoming events anticipated by the company, to which it can actively prepare and anticipate. However, the other substrategies can be classified as reactive. These are changes introduced as a response to unforeseen events to which the company is passively adapting. In addition, depending on the pace of changes, we can distinguish gradual (incremental) changes that are designed to keep the company on the chosen course and strategic (long-term) changes that allow for a total change in the structure or direction of the company's development. These four-field matrix is shown in the Table 6.

Table 6. Four-field adaptation matrix

\begin{tabular}{cccc}
\hline \multicolumn{4}{c}{ Rate (tempo) and type of change } \\
\hline \multicolumn{2}{c}{ Gradual (incremental) } & Strategic (long-term) \\
\hline tuning & reactive & re-orientation & anticipatory \\
reconfiguration & reactive & restoration & reactive \\
\hline Source: own study based on Kreitner R., Management, Houghton Mifflin Company, 2006 [86].
\end{tabular}

Source: own study based on Kreitner R., Management, Houghton Mifflin Company, 2006 [86]

Tuning is a popular least intensive and least risky organizational change. Preventive maintenance as continuous improvement and improvement. Rebuilding, like tuning, includes gradual changes. But here changes are a response to external events, problems and pressures. Re-orientation is a forward and long-term change within a certain framework, the company is redirected, but it does not detach from its current structure, so certain frameworks are changed, but still retain their previous shape. Recreation is the most risky and intense activity in which organizational changes are made under the influence of strong competition.

After conducting the research, a qualitative development of the collected data was made, research statements were formulated and reflection and postulates related to the completed research were formulated. The formulation of conclusions has been clearly divided into (1) cognitive conclusions, which are scientifically proven statements and are part of the state of the art of the current phenomenon in the science of management, and (2) utilitarian conclusions.

\section{Conclusion}

From the research carried out on the group of energy companies, the following cognitive and utilitarian conclusions can be drawn. 


\subsection{Cognitive Conclusions}

- The adaptation strategy is used among enterprises in the regulated sector. Independent variables determine the choice of adaptation strategies;

- Regulations and the technological environment enforce innovation of power companies;

- Financial outlays are needed in power companies to implement new, innovative and expensive technologies;

- Legal and political factors (both national and EU) determine the activities of power companies (in each group: small, medium and large);

- Depending on the size of the company, the intensity of adaptation to the requirements of the environment changes;

- Power companies apply passive adaptation strategies and as they increase their position on the market, they begin to implement an active adaptation strategy;

- Energy companies regularly make the market research to recognize the environment - partners and competitors, as well as their strategy, resources and offers;

- Market research depends on size of the companies (financial aspects of the research).

\subsection{Utilitarian Conclusions}

- Electricity companies should develop the R\&D sphere;

- Power companies should implement innovations because they allow to follow market requirements and adopt to them;

- Electrometric enterprises should implement new business models and observe market trends;

- Electricity companies should go in the direction of energy integration with other industries, especially with the IT industry;

- Startups have a significant role to play in increasing the innovativeness of power companies.

\subsection{Recommendations}

Energy companies and energy global system will need to adopt to impacts of ecology environment and related policies. Appropriate reactions and made (applied) at the right time, i.e. the ability to adapt to upcoming challenges will be crucial for energy security and reliability of energy supply.

Energy companies should analyze issues related to the exploration and extraction of exhaustible energy resources: coal, oil, gas and uranium and consider the potential of renewable energy resources such as hydropower, wind and sun. It is related to the development of new, innovative technologies regarding conventional and renewable energy sources.

\section{Declaration of Competing Interest}

The authors declare that they have no known competing financial interests or personal relationships that could have appeared to influence the work reported in this paper.

\section{References}

[1] Uriona-Maldonado, M., de Souza, L.L.C. \& Varvakis, G. (2010). Focus on practice service process innovation in the Brazilian electric energy sector. Serv Bus 4, 77-88. doi:10.1007/s11628-009-0080-8.

[2] Borowski, P. F. (2015). Ryzyko strategiczne w rozwoju przedsiębiorstw w XXI w.-studium przypadku. Przegląd Organizacji, (2), 14-20.

[3] Wellum, C. (2020). Energizing Finance: The Energy Crisis, Oil Futures, and Neoliberal Narratives. Enterprise \& Society, 21(1), 2-37. doi:10.1017/eso.2019.26.

[4] Eoyang, G. H., \& Holladay, R. J. (2013). Adaptive action: Leveraging uncertainty in your organization. Stanford University Press, California, United States.

[5] Conteh, C., Greitens, T. J., Jesuit, D. K., \& Roberge, I. (Eds.). (2014). Governance and public management: Strategic foundations for volatile times. Routledge, Oxfordshire, England, UK.

[6] Samsami, F., Hosseini, S. H. K., Kordnaeij, A., \& Azar, A. (2015). Managing environmental uncertainty: from conceptual review to strategic management point of view. International journal of business and management, 10(7), 215. 
[7] Thrän, D., Dotzauer, M., Lenz, V., Liebetrau, J., \& Ortwein, A. (2015). Flexible bioenergy supply for balancing fluctuating renewables in the heat and power sector - a review of technologies and concepts. Energy, Sustainability and Society, 5(1). doi:10.1186/s13705-015-0062-8.

[8] Thrän, D., (2018). Being a woman in engineering, Available online: http://blogs.springeropen.com (accessed on May 2019).

[9] Cuervo, Á., Ribeiro, D., \& Roig, S. (2007). Entrepreneurship: concepts, theory and perspective. Introduction. In Entrepreneurship (pp. 1-20). Springer, Berlin, Heidelberg, Germany.

[10] Buchheim, L., Krieger, A., \& Arndt, S. (2019). Innovation types in public sector organizations: a systematic review of the literature. Management Review Quarterly. doi:10.1007/s11301-019-00174-5.

[11] De Vries, H., Tummers, L., \& Bekkers, V. (2018). The diffusion and adoption of public sector innovations: A meta-synthesis of the literature. Perspectives on Public Management and Governance, 1(3), 159-176. doi:10.1093/ppmgov/gvy001.

[12] Pertuz, V., \& Pérez, A. (2020). Innovation management practices: review and guidance for future research in SMEs. Management Review Quarterly. doi:10.1007/s11301-020-00183-9.

[13] Ban, N. C., Mills, M., Tam, J., Hicks, C. C., Klain, S., Stoeckl, N., ... Chan, K. M. (2013). A social-ecological approach to conservation planning: embedding social considerations. Frontiers in Ecology and the Environment, 11(4), 194-202. doi:10.1890/110205

[14] Adger, W. N., Benjaminsen, T. A., Brown, K., \& Svarstad, H. (2001). Advancing a Political Ecology of Global Environmental Discourses. Development and Change, 32(4), 681-715. doi:10.1111/1467-7660.00222.

[15] Briassoulis, H. (Ed.). (2017). Policy integration for complex environmental problems: The example of Mediterranean desertification. Taylor \& Francis.

[16] Cairney, P., McHarg, A., McEwen, N., \& Turner, K. (2019). How to conceptualise energy law and policy for an interdisciplinary audience: The case of post-Brexit UK. Energ policy, 129, 459-466. doi:10.1016/j.enpol.2019.02.022.

[17] Bekun, F. V., Alola, A. A., \& Sarkodie, S. A. (2019). Toward a sustainable environment: Nexus between CO2 emissions, resource rent, renewable and nonrenewable energy in 16-EU countries. Science of the Total Environment, 657, $1023-1029$. doi:10.1016/j.scitotenv.2018.12.104.

[18] Bahrami, H., \& Evans, S. (2014). Super-flexibility for knowledge enterprises: a toolkit for dynamic adaptation. Springer, Berlin, Heidelberg, Germany. doi:10.1007/978-3-642-02447-4.

[19] Gasbarro, F., Rizzi, F., \& Frey, M. (2016). Adaptation measures of energy and utility companies to cope with water scarcity induced by climate change. Business Strategy and the Environment, 25(1), 54-72. doi:10.1002/bse.1857.

[20] Ebinger, J., \& Vergara, W. (2011). Climate Impacts on Energy Systems. doi:10.1596/978-0-8213-8697.

[21] Shen, J., Jiang, C., Liu, Y., \& Wang, X. (2016). A Microgrid Energy Management System and Risk Management under an Electricity Market Environment. IEEE Access, 4, 2349-2356. doi:10.1109/access.2016.2555926.

[22] Pereira, G. I., Specht, J. M., Silva, P. P., \& Madlener, R. (2018). Technology, business model, and market design adaptation toward smart electricity distribution: Insights for policy making. Energy Policy, 121, 426-440. doi:10.1016/j.enpol.2018.06.018.

[23] Wojdalski, J., Dróżdż, B., Grochowicz, J., Magryś, A., Ekielski, A. (2013). Assessment of energy consumption in a meatprocessing plant—a case study. Food and Bioprocess Technology, 6(10), 2621-2629. doi:10.1007/s11947-012-0924-4.

[24] Bickel, M. W. (2019). Reflecting trends in the academic landscape of sustainable energy using probabilistic topic modeling. Energy, Sustainability and Society, 9(1), 1-23. doi:10.1186/s13705-019-0226-z.

[25] Jenkins, A. (2015). Dieter Helm. Energy, the State, and the Market: British Energy Policy since 1979. Oxford, UK, Enterprise \& Society, 5(4), 708-710. doi:10.1017/S1467222700014117.

[26] Jones, C. (2015). The carbon-consuming home: residential markets and energy transitions. Enterprise \& Society, 12(4), 790823. doi:10.1017/S1467222700010685.

[27] Sarbu, I., \& Sebarchievici, C. A. (2018). A Comprehensive Review of Thermal Energy Storage. Sustainability, $10(2), 191$. doi:10.3390/su10010191.

[28] Appiah-Adu, K., \& Bawumia, M. (2016). Key determinants of national development: historical perspectives and implications for developing economies. Routledge.

[29] Borowski, P. F. (2016). Development Strategies for Electric Utilities. Acta Energetica, 4(29), 16-21. doi:10.12736/issn.23003022.2016402 .

[30] Onwuegbuzie, A. J., \& Collins, K. M. (2007). A typology of mixed methods sampling designs in social science research. Qualitative Report, 12(2), 281-316. 
[31] Bazeley, P. (2015). Mixed methods in management research: Implications for the field. Electronic Journal of Business research Methods, 13(1), 27-35.

[32] Van der Roest, J.-W., Spaaij, R., \& van Bottenburg, M. (2013). Mixed Methods in Emerging Academic Subdisciplines. Journal of Mixed Methods Research, 9(1), 70-90. doi:10.1177/1558689813508225.

[33] Najda-Janoszka, M., \& Daba-Buzoianu, C. (2018). Editorial Paper: Exploring Management Through Qualitative Research Introductory Remarks. Journal of Entrepreneurship, Management and Innovation, 14(4), 5-16. doi:10.7341/20181440.

[34] Butterfield, K. D., Reed, R., \& Lemak, D. J. (2004). An Inductive Model of Collaboration from the Stakeholder's Perspective. Business \& Society, 43(2), 162-195. doi:10.1177/0007650304265956.

[35] Jeszka, A. M. (2013). Problemy badawcze i hipotezy w naukach o zarządzaniu. Organization and Management, 5 (158), 31 -39.

[36] Mroczko, F. (2014). Jakościowe metody badań: obserwacja naukowa. Prace Naukowe Wałbrzyskiej Wyższej Szkoły Zarządzania i Przedsiębiorczości, 26, 65-78.

[37] Shank, G. D. (2002). Qualitative research: A personal skills approach. Upper Saddle River, NJ: Prentice Hall, New Jersey, United States.

[38] Keusch, F. (2015). Why do people participate in Web surveys? Applying survey participation theory to Internet survey data collection. Management Review Quarterly, 65(3), 183-216. doi:10.1007/s11301-014-0111-y.

[39] Lawson, A. E. (2005). What is the role of induction and deduction in reasoning and scientific inquiry? Journal of Research in Science Teaching, 42(6), 716-740. doi:10.1002/tea.20067.

[40] Bendassolli, P. F. (2013). Theory building in qualitative research: Reconsidering the problem of induction. In Forum Qualitative Sozialforschung/Forum: Qualitative Social Research 14(1). doi:10.17169/fqs-14.1.1851

[41] Stenbacka, C. (2001). Qualitative research requires quality concepts of its own. Management Decision, 39(7), 551-556.

[42] Qu, S. Q., \& Dumay, J. (2011). The qualitative research interview. Qualitative Research in Accounting \& Management, 8(3), 238-264. doi:10.1108/11766091111162070.

[43] Chalikias, M., Lalou, P., \& Skordoulis, M. (2019). Customer Exposure to Sellers, Probabilistic Optimization and Profit Research. Mathematics, 7(7), 621. doi:10.3390/math7070621.

[44] Guiasu S, 2009. Probabilistic models in operations research. Nova Science Publishers, New York, United States.

[45] Hyde, K. F. (2000). Recognising deductive processes in qualitative research. Qualitative Market Research: An International Journal, 3(2), 82-90. doi:10.1108/13522750010322089.

[46] Dźwigoł, H., \& Dźwigoł-Barosz, M. (2018). Scientific research methodology in management sciences. Financial and credit activity: problems of theory and practice, 2(25), 424-437.

[47] McKinley, W., \& Mone, M. A. (2005). Micro and Macro Perspectives in Organization Theory: A Tale of Incommensurability. Oxford Handbooks Online. doi:10.1093/oxfordhb/9780199275250.003.0013.

[48] Law J. (2009), A Dictionary of Business and Management (5ed.) Oxford University Press, Oxford, United Kingdom.

[49] Patuk, I., \& Borowski, P. F. (2017). Business plan of the company of repair and maintenance outboards and boats"Technoservice". World Scientific News, 86(3), 193-204.

[50] Shilei, L., \& Yong, W. (2009). Target-oriented obstacle analysis by PESTEL modeling of energy efficiency retrofit for existing residential buildings in China's northern heating region. Energy Policy, 37(6), $2098-2101$. doi:10.1016/j.enpol.2008.11.039.

[51] Song, J., Sun, Y., \& Jin, L. (2017). PESTEL analysis of the development of the waste-to-energy incineration industry in China. Renewable and Sustainable Energy Reviews, 80, 276-289. doi:10.1016/j.rser.2017.05.066.

[52] Yüksel, I. (2012). Developing a multi-criteria decision making model for PESTEL analysis. International Journal of Business and Management, 7(24), 52. doi:10.5539/ijbm.v7n24p52.

[53] Borowski, P. F. (2019). Adaptation strategy on regulated markets of power companies in Poland. Energy \& Environment, 30(1), 3-26. doi:10.1177/0958305X18787292.

[54] Gao, F., Li, M., \& Nakamori, Y. (2002). Systems thinking on knowledge and its management: systems methodology for knowledge management. Journal of knowledge management. 6(1), 7-17. doi:10.1108/13673270210417646.

[55] Jackson, M. C. (2007). Systems approaches to management. Springer Science \& Business Media, Springer, Boston, MA, United States. doi:10.1007/b100327.

[56] Clarke, S. (2012). Information systems strategic management: an integrated approach. Routledge, London, United Kingdom. 
[57] Godin, B. (2009). National innovation system: The system approach in historical perspective. Science, Technology, \& Human Values, 34(4), 476-501. doi:10.1177/0162243908329187.

[58] Kunc, M. (Ed.). (2017). System dynamics: soft and hard operational research. Springer. Boston, MA, United States.

[59] Ross, A. M., Rhodes, D. H., \& Hastings, D. E. (2008). Defining changeability: Reconciling flexibility, adaptability, scalability, modifiability, and robustness for maintaining system lifecycle value. Systems Engineering, 11(3), 246-262.

[60] Bastholm, C., \& Henning, A. (2014). The use of three perspectives to make energy implementation studies more culturally informed. Energy, Sustainability and Society, 4(1). doi:10.1186/2192-0567-4-3.

[61] Krzakiewicz, K., \& Cyfert, S. (2014). The strategic dimension of the dynamic capabilities of enterprises. Management, 18(2), 7-18.

[62] Krzakiewicz, K., \& Cyfert, S. (2017). Dynamic capabilities in strategic choice processes within organisations. Management, 21(1), 7-19.

[63] Stieglitz, N., Knudsen, T., \& Becker, M. C. (2015). Adaptation and inertia in dynamic environments. Strategic Management Journal, 37(9), 1854-1864. doi:10.1002/smj.2433.

[64] Hannan, M. T., \& Freeman, J. (1984). Structural Inertia and Organizational Change. American Sociological Review, 49(2), 149. doi:10.2307/2095567.

[65] Zhang, C. M., \& Greve, H. R. (2016). Delayed Adoption of Rules: A Relational Theory of Firm Exposure and State Cooptation. Journal of Management, 44(8), 3336-3363. doi:10.1177/0149206316673719.

[66] Pérez-Nordtvedt, L., Khavul, S., Harrison, D. A., \& McGee, J. E. (2013). Adaptation to Temporal Shocks: Influences of Strategic Interpretation and Spatial Distance. Journal of Management Studies, 51(6), 869-897. doi:10.1111/joms.12050.

[67] Canato, A., Ravasi, D., \& Phillips, N. (2013). Coerced Practice Implementation in Cases of Low Cultural Fit: Cultural Change and Practice Adaptation During the Implementation of Six Sigma at 3M. Academy of Management Journal, 56(6), $1724-1753$. doi:10.5465/amj.2011.0093.

[68] Magnusson, P., Westjohn, S. A., Semenov, A. V., Randrianasolo, A. A., \& Zdravkovic, S. (2013). The Role of Cultural Intelligence in Marketing Adaptation and Export Performance. Journal of International Marketing, 21(4), 44-61. doi:10.1509/jim.13.0055.

[69] Eakin, H. C., \& Patt, A. (2011). Are adaptation studies effective, and what can enhance their practical impact? Wiley Interdisciplinary Reviews: Climate Change, 2(2), 141-153. doi:10.1002/wcc.100.

[70] Seroka-Stolka, O., Krawczyk-Sokołowska, I., \& Grabowska, M. (2016). Environmental management models. Science. Business. Society, 1(1), 49-52.

[71] Andries, P. and Debackere, K. (2006). Adaptation in new technology-based ventures: insights at the company level. International Journal of Management Reviews, 8, 91-112.

[72] Andries, P., \& Debackere, K. (2007). Adaptation and performance in new businesses: Understanding the moderating effects of independence and industry. Small business economics, 29(1-2), 81-99.

[73] Rutherfor, T., Parker, P., \& Koshiba, T. (2010). Global, Local, or Hybrid?: Evidence of Adaptation among Japanese Automobile Plants in Japan, the United States and Canada. Environments: a journal of interdisciplinary studies, 29(3).

[74] Saebi, T., Lien, L., \& Foss, N. J. (2017). What Drives Business Model Adaptation? The Impact of Opportunities, Threats and Strategic Orientation. Long Range Planning, 50(5), 567-581. doi:10.1016/j.lrp.2016.06.006.

[75] Garbara W. (1969), Proces przystosowawczy przedsiębiorstwa do środowiska, PWE, Poland.

[76] Chakravarthy, B. S. (1982). Adaptation: A promising metaphor for strategic management. Academy of Management Review, $7(1), 35-44$.

[77] Miles, R. E., \& Snow, C. C. (1978). Organizational strategy, structure, and process McGraw-Hill. New York, United States.

[78] Ogunmokun, G. O., \& Li, L. Y. (1999). Globalization versus adaptation strategy in international marketing: a study of exporting companies in the people's republic of China. Asian Academy of Management Journal, 4(2), 23-38.

[79] Chakravarthy, B. S. (1982). Adaptation: A Promising Metaphor for Strategic Management. Academy of Management Review, 7(1), 35-44. doi:10.5465/amr.1982.4285438.

[80] Satapathy, S., Patel, S.K., Biswas, A. et al. (2012). Interpretive structural modeling for E-electricity utility service. Serv-Bus 6, 349-367 doi:10.1007/s11628-012-0139-9.

[81] Lange, S., Pohl, J., \& Santarius, T. (2020). Digitalization and energy consumption. Does ICT reduce energy demand? Ecological Economics, 176, 106760. doi:10.1016/j.ecolecon.2020.106760. 
[82] Naranjo-Gil, D., \& Hartmann, F. (2007). Management accounting systems, top management team heterogeneity and strategic change. Accounting, Organizations and Society, 32(7-8), 735-756. doi:10.1016/j.aos.2006.08.003.

[83] Center for Creative leadership (2013), Adapting to Organizational Change, Greensboro, N.C.: CCL Press, North Carolina, United States.

[84] McCardle, J. G., Rousseau, M. B., \& Krumwiede, D. (2019). The effects of strategic alignment and competitive priorities on operational performance: The role of cultural context. Operations Management Research, 12(1-2), 4-18.

[85] Borowski P. F. (2020) Zonal and Nodal Models of energy market in European Union, Energies, 13(16), 4182; doi:10.3390/en13164182

[86] Kreitner R., (2006). Management, Houghton Mifflin Company. Houghton Mifflin College Div, Boston, Massachusetts, United States.

[87] Zakrzewska-Bielawska, A. (2018). The Relationship between Managers' Network Awareness and the Relational Strategic Orientation of their Firms: Findings from Interviews with Polish Managers. Sustainability, 10(8), 2691. doi:10.3390/su10082691.

[88] Leonard, A., \& Grobler, A. F. (2006). Exploring challenges to transformational leadership communication about employment equity. Journal of Communication Management, 10(4), 390-406. doi:10.1108/13632540610714827.

[89] Dettmer, S. L., Pagliara, S., Misiunas, K., \& Keyser, U. F. (2014). Anisotropic diffusion of spherical particles in closely confining microchannels. Physical Review E, 89(6). doi:10.1103/physreve.89.062305.

[90] Hatum, A., \& Pettigrew, A. M. (2006). Determinants of Organizational Flexibility: A Study in an Emerging Economy. British Journal of Management, 17(2), 115-137. doi:10.1111/j.1467-8551.2005.00469.x.

[91] Scott, W. R., \& Davis, G. F. (2015). Organizations and organizing: Rational, natural and open systems perspectives. Routledge.

[92] Manolova, T. S., Eunni, R. V., \& Gyoshev, B. S. (2007). Institutional Environments for Entrepreneurship: Evidence from Emerging Economies in Eastern Europe. Entrepreneurship Theory and Practice, 32(1), 203-218. doi:10.1111/j.15406520.2007.00222.x

[93] Sánchez, A., Lago, A., Ferràs, X., \& Ribera, J. (2011). Innovation Management Practices, Strategic Adaptation, and Business Results: Evidence from the Electronics Industry. Journal of Technology Management \& Innovation, 6(2), 14-39. doi:10.4067/s0718-27242011000200002. 